\title{
Thematic and Contextual Reflection of Women in 'Honour Unmasked' by Nafisa Shah
}

\author{
Surryia Khanum ${ }^{1 *}$, Dr. Muhammad Arfan Lodhi ${ }^{2}$, Anila Hashim ${ }^{3}$ \\ ${ }^{1}$ Surryia Khanum M.Phil Scholar NCBA\&E University Lahore, Pakistan \\ ${ }^{2}$ Higher Education Department (Collegiate Wing) Punjab, Pakistan \\ ${ }^{3}$ M.Phil Scholar NCBA\&E University Lahore, Pakistan
}

DOI: $10.36348 /$ jaep.2022.v06i01.004
*Corresponding author: Surryia Khanum
M.Phil Scholar NCBA\&E University Lahore, Pakistan

\section{Abstract}

The purpose of this research is to provide light on the trauma experienced by females in Pakistan, particularly in upper Sindh. This research shall show how women are murdered in the name of honor as a result of this investigation. Nafisa Shah, the author of this book, has worked as a journalist, researcher, and administrator. She is from upper Sindh, which explains why she went into depth about the genuine unpleasant truths of Karo kari (A detestable ritual). The author recounts the instances of women who were assassinated in the sake of honor. Additionally, she highlights the experiences of women who strive for their life, escape, and successfully survive. Karo kari is a colloquial term for honor killing. Karo kari, or honor killing, is a long-standing ritual in rural Pakistan, particularly in upper Sindh. Nafisa Shah is a writer who stumbled into politics. In Pakistan, honor killing is referred to as karo kari. This deed is performed in order to restore the family's honor. This is a widespread practice in Pakistan, particularly in upper Sindh. Activists on both the international and Pakistani levels are working to end this practice. A qualitative approach has been used to analyses the text of Nafisa shah in order to get the desired answers.

Keywords: Karol-kari (Ritual); Emancipation; Honor Killing; Women Plight.

Copyright $\odot 2022$ The Author(s): This is an open-access article distributed under the terms of the Creative Commons Attribution 4.0 International License (CC BY-NC 4.0) which permits unrestricted use, distribution, and reproduction in any medium for non-commercial use provided the original author and source are credited.

\section{INTRODUCTION}

It is not just the civilizations of South Asian and Islamic origins that murder for the sake of honor. In many regions of the globe, individuals of many faiths, ideologies, and worldviews continue to engage in this ancient practice, which is being practiced today. Traditionalism and contemporary legalism are at odds with this statute, which has caused considerable division. Author Nafisa Shah has attempted to uncover the reasons and mechanisms behind the rise in popularity of the karo-kari ritual in upper Sindh. The findings of an anthropologist's investigation revealed a plethora of complexities, which should come as no surprise (Shahraz, 2001).

Nafisa Shah is a writer. She is a journalist, social activist, and politician. Her father was Sindh's exchief minister. She has been writing about honor killing for over a decade. She was the Khair Pur district's mayor. She is well versed in the upper Sindh culture, customs, values, and system. She has greater understanding of female concerns since she lives in the region where this deadly act of Karo kari occurs. A male relative might murder his lover or lover's if he feels his honor has been damaged owing to their sexual connection, according to the author. if the relationship is not sanctified by marriage.

As a woman from an upper-class family of local origin who has received training as an anthropologist from Oxford, Nafisa explains the perplexing realities in a series of binaries, such as law versus lawlessness, right and wrong, justice versus violence, state versus non-state, normative and legal, to explain the violence in Kacho, which is the area beyond river embankments. This geographic split represents the power dynamics of civilization and barbarism in terms of territory and population (Weiss, 2016). The author analyses her own shifting positions as a journalist, investigator, researcher, mayor of Khairpur, and eventually legislator in relation to the study's topic of honor killing and finds a counter-dialogue of peace. Her political popularity was threatened, and she had to deal with fabricated reports, pleas, political pressures, and 
Surryia Khanum et al., J Adv Educ Philos, Jan, 2022; 6(1): 24-29

political threats in order to keep her from adopting an impartial or legal stance on such incidents of violence (Ahmad, 1991).

She also noted that, in her capacity as mayor of Khairpur, she has spent a significant amount of time attending weddings and grieving the deaths of friends and family members. This is vital to emphasize that the book is neither the result of scholarly study nor the work of a district officer who had access to police and court data, but rather has more to say than either of these. The power dynamic that women in Pakistan face, despite the regular imports of current and liberal notions, is a result of the country's historical feudal system. Since 1992, she has also been investigating this long-standing customary practice, and it is important to mention that laws have been passed to outlaw such violence when it occurs on occasion. Unsurprisingly, karo-kari news has travelled so far, and the perpetrators have shown such courage in carrying out their crimes, that the law has become a farce. The occurrence of such violence is not just a direct result of accusations of having sexual or unlawful connections, but also as a result of marriages by choice, which is considered a sin in this community if it is not sanctioned by close relatives (Niaz Muhammad, 2012).

\subsection{Background to the study}

The research focuses on the subject of honor killing in Pakistan, particularly in upper Sindh. This investigation will reveal how women are assassinated in the sake of honor. Nafisa Shah, the author of this book, has worked as a journalist, researcher, and administrator. She is from the upper Sindh, which is why she detailed the genuine harsh truths of Karo kari. The author narrates the experiences of women who were murdered in the sake of honor. She also exposes the experiences of women who are fighting for their life, escaping, and successfully surviving (Muazzam Nasrullah, 2009). In Pakistan, honor killing is referred to as karo kari. This deed is carried out in order to restore the family's honor. It is a widespread practice in Pakistan, particularly in upper Sindh. International and Pakistani activists are working hard to put an end to this practice.

The book is divided into three parts. The first part is very important that explain the concept of karo kari or honour killing. It also describes the reason of karo kari and power involvement in this shameful act. This part also explains that it is a customary practice. The second part is about Law, power and honor. This part expresses how this act of karo kari is taking place with the name of honor and law. It also elaborates the relationship of law and custom. The writer discusses actual cases of honor killing and tells the reality that it is not a timeless problem but it has become the form of violence which is informed by recent changes in the law. The third part is very important that deals the practice of justice in traditional manners. It also explains the life of missing women of upper Sindh. This part also explains the agencies which are active in this issue of honor killing. It also elaborates the role of judges, police and tribal chief.

\subsection{Rational of the Study}

In the book, Nafisa Shah sheds attention to several concerns affecting women who have been subjected to the heinous practice of karo kari. She also emphasizes that the karo kai problem is related to the so-called honorable killing, but that this practice occurs to conceal various shades of power struggle. This technique was largely developed by males to defend their economic, political, social, and other interests. The study's goal is to evaluate the text in order to understand the origins of the horror act of karo kari. The study's aim is to investigate the trauma of karo kari, which often occurs for the benefit of men's own interests. This study also brought attention on the women who are subjected to this practice and flee in order to save their lives. The research will also look at the link between law and customs. This report also outlines the role of our law enforcement and other organizations that work to improve the lives of women (Saima Afzal, 2016).

\subsection{Research questions}

1: How the act of karo kari linked to honor killing in upper Sindh?

2: What is the role of non-governmental organizations, the law, and honor killing?

3: How do males use honor killing to safeguard their economic, power, and political interests?

\subsection{Exploratory Significance}

This study is significant in a variety of ways. Initially, it sheds light on the origins and causes of karo kari. At the same time, it explores how the women of upper Sindh suffer as a result of this heinous conduct. It also exposes the stories of the ladies who escape in order to save their own lives. This research also provided light on the involvement of institutions such as police and courts in honor killing. This book sheds light on the missing ladies of upper Sindh as well as the alleged lovers.

\section{LITERATURE REVIEW}

Kumar (2018) described about an Italian girl, named Sana Cheema who was killed suspiciously in Pakistan. He is of the view that this is not first incident in Pakistan. Qandeel Baloch who was a social media star was also killed by her brother to her family honor. He suggested that there is no religion in the world which allows anyone to kill his female. A love marriage, divorce, rape, dowry and illicit connection are the only reasons for honor killing. No religion, nation, or community condones honor killing. Honor killings are carried out to control women. Its origins span thousands of years and civilizations. Today the world accused Muslims for honor killings, but the truth is that the west sponsored them. He urged ending the practice 
Surryia Khanum et al., J Adv Educ Philos, Jan, 2022; 6(1): 24-29

of honor killing. To defend our ladies, all intellectuals must support the women's rights law. Assuring the public that honor killing has no place in society. Parents must also accept the digital age. They must assist their daughters if they choose to marry outside the family.

Masood et al. (2010) has stated that the approach to honor is social and cultural. It is the cognitive setting of the individuals that is imposed by society. Women are seen as hurdles to family honor not just in Pakistan, but practically elsewhere in the globe. They are merely born to follow the standards and values established by society. They went on to say that, according to a ministry of interior study, around 5000 women are slaughtered each year in the sake of honor. Honor killing has been documented in various parts of the globe, including Pakistan. According to court records from 1995, 89 women were murdered in Jordan in the sake of honor. A cross-sectional survey is used to acquire the data.

\subsection{Women's perspective in literature}

Lang (2008) is of the view that many critics believe that the writing of male and female writing about female is different due to their lives experiences as a male and female both have different life approach regarding life. Some argue that men authors cannot write feminine issues as well as female writers. Their outlook on life is different. Female writers mainly represent women's lives in writing. Gender plays a key part in our existence. From birth, male and female are put on a road to conform to society's harsh standards of life. In patriarchal culture, women are educated to feel inferior. She is forced to live a life defined only by men. He said that American, African, and other authors provide a definite female viewpoint in literature." she's come undone" by Wally Lamb, published in 1992. It relates Dolores' tale. She battles abandonment, rape, and weight. The book is recounted from the viewpoint of a female.

"La femme du mari inconnu" is a short tale by Edgar Okiki Zinsou. The narrative is about Cicavi, an impoverished young lady who is forced to marry a stranger by her mother for money. It is written in third person female. Whether authored by a man or a woman, writings written from a woman's viewpoint have similar challenges. In all books, women's lives are terrible. Men's actions cause tragic occurrences like desertion, divorce, and forced marriage. All writers whether from the USA, Europe or post-colonial countries express sympathies with women while reflecting their plight and undue treatment in male chauvinist society.

Writers in Pakistani literature attempt to emphasize the plight of women in Pakistani society. Pakistani society is a patriarchal society constructed by males. It is a conservative culture. Pakistani authors touch on the difficulties, struggles, and opposition against patriarchal institutions. Women in Pakistan, according to largely Pakistani authors, are battling to show their identity and value. They want to live their own lives, lives that are independent of patriarchal structures. Women want to demonstrate that they are just as vital to society as males are. They, like males, can contribute to the nation. Sidhwa (1990) in "The Pakistani bride" explained different social issues of women such as marriage and victimization. The writer described a Zaitoon survivor. She was a split kid. Qasim rose after losing her parents. Qasim arranged her marriage. She didn't want to marry but was forced by Qasim. Her struggle begins on day one. After two months of marriage, she was punished by her husband for going to the river alone. To leave the savage tribal society, she overcame life's trials. Unfamiliar steep terrain saved her life. Her spouse killed her. She died; he was told. The author aims to highlight how society treats women. The author dwelt on the plight of women in tribal communities.

His contributions to Pakistani English literature are many. Women's traditional norms are described in Sidhwa. She did her utmost to represent the social condition of women. She became the voice of women. In Pakistani literature, women are inferior and must follow the men's way. Men abuse not just due to family ethics and ideals, but even religious principles for monetary gain. Religion, society, and conventions oppress women. Male supremacy over female is ingrained. Husbands, brothers and dads govern women's life. In Pakistani literature, women are considered as symbols of masculine dignity. Honor is sacrificed by their father, brother and spouses.

Mauzzam et al. (2009) described honor killing or violence against women is a public health concern issue. In 48 surveys throughout the globe, 10-69 percent of women experience physically or emotionally abuse by their male partners. The Dawn, Nawaie-e- Waqat, Khabrain and Jang are Pakistan's biggest Urdu and English language broadsheets, according to several national newspapers. These publications routinely report on honor killings around the nation. The report covered the act of honor killing briefly. (HRCP) prepared a report after reading about honor killing in the press. The report details the victims' socioeconomic and marital status, the weapon used in the killing, and the victims' medical care.

Afshan et al. (2019) highlighted the importance of institutions in forming culture. The law promotes honor killing. Women are discriminated against by the police, the judges, and attorneys. Due to the backing of male guardians of women, the police and judges have a tough time prosecuting any guy who commits this crime of honor killing. Any woman seeking liberation from patriarchal social norms and ideals must confront harsh repercussions, even the loss of her life. Sadiq et al. (2013) highlighted an ethnographic field research done in Jacobabad, Sindh, 
Surryia Khanum et al., J Adv Educ Philos, Jan, 2022; 6(1): 24-29

honor killing is not just a result of customs and traditions, but also a result of feudal culture, the law, and societal systems that favor male dominance. He continued by stating that honor killings may be halted if feudal lords refrain from interfering with governmental institutions, particularly the police and the judiciary. It may also be avoided by educating the populace.

\section{METHODOLOGICAL FRAMEWORK}

Research is described as an activity that identifies and resolves an undiscovered issue. The term "technique" refers to the process of developing a research methodology and selecting a suitable design for performing the study. This study used an exploratory framework in conjunction with a case-based research approach. The available population was obtained from the book honor exposed by Nafisa shah. Qualitative data collection and analysis were used. Qualitative data analysis approaches use a pragmatic approach to data analysis. Data are analyzed using the content analysis approach. The framework for data analysis is provided. The population of the study is the book Nafisa Shah named Honour Unmasked as well as the articles and journals from the digital medium.

\subsection{Framework of Analysis}

The text has been analyzed on several levels by adopting particular and focused framework of analysis. This research discusses women's contextual reflection. The cultural concerns, the position of the tribe chief, the role of male members, the status of women, and issues of honor killing, sexual misconduct, and domestic violence are explored rationally as subcategories.

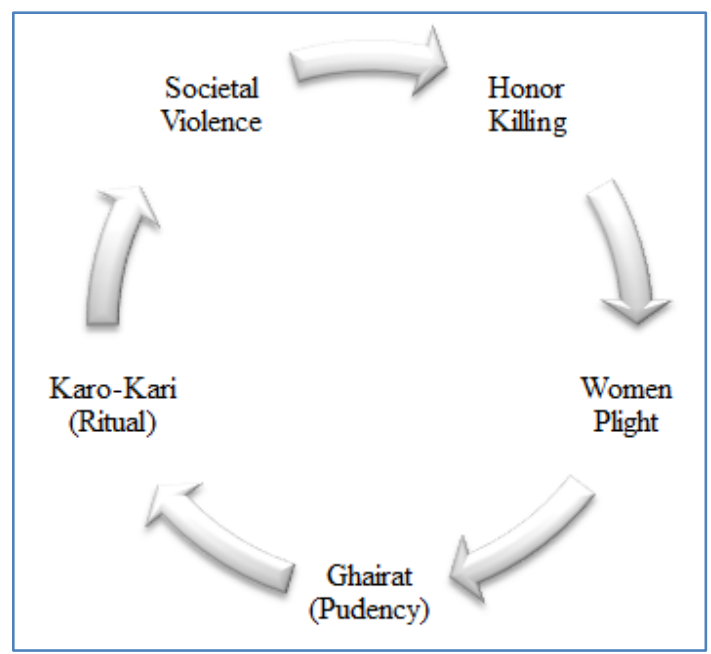

\section{ANAL YSIS AND DISCUSSIONS}

The text demonstrates several damaging components of power, politics, and male dominance multilaterally dispersed across culture religion and ethnicity. Additionally, various reasons of honor killing are discussed, such as women being killed to defend their property. Nafisa Shah illuminates several women's socioeconomic difficulties in order to bring attention to her own troubles with honor killing (Afshan Kiran Imtiaz, 2019). Every religion granted women equal rights. Society establishes norms for women. Male members assassinate their female counterparts in order to save their honor. Ghairat (Pudency) is also a major cause of honor killings. As Shah explains ghairat.

Ghairat involves the interplay of emotions of anger, silence and loss, and disable a person from seeing anything else around him. The emotional experience of ghairat shuts out the entire range of social, historical, and cultural factors that have the potential of helping to understand the situation. (Shah 2017, Page.58).

Entrapment is defined as the act of encouraging someone to breach the law with the goal of suing the person for it. The book has the aspect of entrapment. A woman has no option but to live her own life, especially when she has chosen a guy as her spouse. The book paints a bleak image of upper Sindh, where honor killing is at its pinnacle. In the hands of her male member, she is treated like an animal. The author explores genuine incidents of honor killing and explains that it is not a timeless phenomenon, but it has evolved into a type of violence inspired by current legal developments. Honor killing is a traditional practice (Nasir, 2018). As Shah said in her book.

Understood popularly as a rasm or as a 'custom' that sanctions death or eviction to men and women accused of sexual transgressions, karo kari has become one of the lead stories in Pakistani national media, a major human right issue, and a problem both civil society and law makers are concerned about (Shah, 2017, Page.1).

The book depicts women as objects of tyranny, with the goal of killing them in the name of honor. The book discusses social trapping as well as familial concerns. According to the author, most women are slain for the sake of honor, while males survive because they pay a price for honor harm. Material exchange is also very significant. A black guy survives because he has more weapons and land.

The headman of Ulro village, Sardar Lutuf ulro, who likes to speak English when discussing karokari killings said, it is an old custom. I do not know who invented it. He then listed Islam, riwaj or custom, poor government, a corrupt judiciary, a hypocritical tribal chief 'who never made his own family women black but decided about poor people's women', poverty, and lack of justice as the underlying causes of the present practice. (Shah, 2017 Page.74).

Numerous women are murdered in the name of honor, and more attempt to flee. Numerous women succeed in escaping and leading prosperous lives. The 
Surryia Khanum et al., J Adv Educ Philos, Jan, 2022; 6(1): 24-29

book also discusses social issues. Society and patriarchy both contribute to the murdering of women for the sake of honor. The research also discusses the roles of power. According to Shah, the majority of women slain to preserve honor include widows, separated spouses, elderly and ailing women, young girls, childless women, and wealthy moms with eager kids. These ladies are murdered for the purpose of acquiring property (Sadiq Bhanbhro, 2013). Shah mentions in her book a childless, divorce women that her husband's sister-in-law and her son made a plan to make her black because they wanted her husband's property.

Shah (2017) declares that "Power is clearly a factor in the karo kari phenomenon in upper Sindh, as women and girls are primary targets because they are weak, dependent, and in the custody of men". The author examined how women are treated in a maledominated culture. She believes that society determines women's standing. Additionally, this research assesses the difficulties experienced by women who practice karo-kari.

These aspects have been reported before; for example, Sheen Farrukh's Kari Zakhm and comparable literature. The practise of karo-kari has been interwoven into the web of power relations by Nafisa Shah in this book. The author demonstrates, using real court cases, that the state legal system is exploited by competing groups, and that the winner receives a lot of benefits in addition to the power to shame the women of the opposing society, and therefore indirectly, males as well. Despite the fact that the truth is proclaimed in court, interpretations are more important than facts. The parties on the perimeter utilize a variety of pressure techniques, such as transferring investigative personnel, fabricating new cases, and blaming the police, among others. Traditional conflict resolution methods are used, and spiritual people are also engaged.

The role of plaintiff, having assumed the status of wali (guardian), who normally has power over the life and death of a murdered person, is helpful in settling disputes, but Nafisa Shah argues that, because of the heinous role such wali plays in perpetuating karokari practice, this role should now be adopted by the state, as it has been done in the United States, to ensure justice in the murder-'a crime against state' (ibid).

Shah (2017) has attempted to prove, in the light of growing trends and via her excellent research, that the ideology of ghairat is unfounded, and that the term and excuse of ghairat is utilized "as a tool for other aims." Even the idea that the doctrine was brought to Sindh by Baloch tribes is false, since any such incident in Balochistan ended in divorce rather than murder. As a result, she joins the ranks of writers and women's rights campaigners who argue that "killing has no honour." True, they degrade women and men by killing them and discarding their carcasses for animals to consume.

Meanwhile, the author believes that all victim women will not be hushed or disregarded indefinitely because of her strong feminist convictions. Through Sindh, their voices are heard in a new style of poetry and fiction. This voice is dedicated to defending the freedom to love and marry out of free choice, as well as lamenting the fate of those who have been tortured to death for 'love.' These authors and artists portray women as victims of male aggression, exposing the society's hypocrisy and criminal silence.

\section{JUSTIFICATION OF THE RESEARCH QUESTIONS}

The researchers found that bardri (community) and caste is a male-dominated social structure in Sindhi civilization. The power, authority, and identity of the head/chief and other male members of the group are defined by caste, bradri, or clan. A number of young women have been slain in the sake of 'honour,' including those who married men from other bardri, casts, or clans. According to the findings, maledominated social institutions play a significant role in the community, controlling all areas of women's life. Family, caste/ braderi/tribe, marriage, and Jirga are examples of these institutions. Men impose societal limitations, a practise of tight gender segregation, certain kinds of family and kinship, and a relationship between family honour and female 'virtue' via these systems. The family, as a fundamental social structure, is a male-dominated system in which male family members wield control and authority over female family members. Because the act is perpetrated by male family members against female family members, the family plays a critical part in this. "Woman is izat [honour] of a man and his khandan [family], and if she dishonours, she is punished".

Marriage is a social institution that represents the community's male-dominated social structure. Endogamy is often used in rural traditional settings to perpetuate patrimony or patriarchy. The parallel cousin marriage is usually practised to maintain the endogamy. When a woman of a family dares to decide free will marriage and breaks the endogamous marriage tradition she is branded as kari and in most cases murdered.

'Honour killing,' is a complicated phenomenon that encompasses a wide range of social, political, ideological, legal, and psychological variables. As a result, marital problems and gender discrimination are implicated in the filing of a FIR, as well as the motivation for reporting such a murder, which is to collect money via mediation and compensation. The study discovered that the socially produced event of karo kari is inherently linked to mediation, and that mediation impacts karo-kari creation rather than the 
Surryia Khanum et al., J Adv Educ Philos, Jan, 2022; 6(1): 24-29

other way around. If a man is killed, there is a greater chance that the killing will be challenged in both conflict and the legal system. If a lady is slain, her complaint will be filed on her behalf by the same persons who killed her.' As far as the matter of other agencies is concerned victims may become politically active actors in their own right, seeking protection from the state in order to exercise their freedom to marry whoever they choose. When such victims return to their communities, however, they are unable to live with an open face. This position, which the author refers to as "social death," also affirms the authority of traditions while rejecting the state's ability to allow people to exist in dignity.

\section{CONCLUSION}

According to the author, the research established the many causes of karo kari. On the basis of current trends and her thorough study, Nafisa has attempted to establish that the ideology of ghairat is untrue, and that the term and reason for ghairat are being used "as a weapon for other aims." Furthermore, the allegation that Baloch tribes brought the philosophy to Sindh is false, since any comparable incident in Balochistan would have ended in divorce rather than murder. So, she has joined the ranks of feminists and writer who believe that "killing has no honor." True, they degrade women and men by killing them and abandoning their remains for animals to consume, but they also degrade themselves by doing so (Jan, 2018).

The research demonstrates that women are nothing more than a toy in the hands of their male counterparts. Additionally, this research discovered the anguish, grief, and trauma endured by upper Sindh females. Women are unjustifiably abused throughout the book. Additionally, this research demonstrated how women in upper Sindh flee for their life. Additionally, this investigation discovered information about upper Sindh's customs and traditions. According to the author's reading of the book's content, no woman should be confined to the four walls of the home. It is her legal right to marry her preferred individual (Zakaria, 2018). The results indicate that women are treated less favorably as a result of society-imposed regulations. Women are seen as subservient to males in terms of societal norms and ideals. As a result, it is critical that women and men be treated equally under the law.

\section{REFERENCES}

- Afshan Kiran Imtiaz, F. M. (2019). Honour Killings of Women in Punjab: A Socio-Political Context. Retrieved from http://journals.pu.edu.pk/journals/index.php/IJSAS/ article/view/3269.

- Ahmad, R. (1991). We Sinful Women: contemporary Urdu Feminist poetry. Retrieved from https://www.worldcat.org/title/we-sinful- women-contemporary-urdu-feministpoetry/oclc/872095112?referer=di\&ht=edition.

- Bapsi Sidhwa, S. B. (1990). The Pakistani Bride. Retrieved from https://penguin.co.in/book/thepakistani-bride/.

- Jan, N. G. (2018). Pakistan: No Honour in Killing. Retrieved from https://www.internationalaffairs.org.au/australianou tlook/pakistan-no-honour-in-killing/.

- Lange, C. (2008). Men and Women Writing Women: The Female Perspective and Feminism in U.S. Novels and African Novels in French by Male and Female Authors. Retrieved from.

- Masood Ali Shaikh, I. A. (2010). Attitudes about honour killing among men and women--perspective from Islamabad. Retrieved from https://pubmed.ncbi.nlm.nih.gov/22338414/.

- Muazzam Nasrullah, S. H. (2009). The epidemiological patterns of honour killing of women in Pakistan. Retrieved from https://pubmed.ncbi.nlm.nih.gov/19286837/.

- Nasir, M. H. (2018). A Girl In The River: A Critical Discourse Analysis Of Honor Killing. Retrieved from https://www.prdb.pk/article/a-girlin-the-river-a-critical-discourse-analysis-of-honor9283.

- $\quad$ Niaz Muhammad, M. M. (2012). Honor Killing in Pakistan: An Islamic Perspective. Retrieved from https://www.ccsenet.org/journal/index.php/ass/artic le/view/19336.

- Sadiq Bhanbhro, M. R. (2013). Bhanbhro, S., Wassan, M. R., Shah, M., Talpur, A. A., \& Wassan, A. A. (2013). Karo Kari: the murder of honour in Sindh Pakistan: an ethnographic study. International Journal of Asian Social Science, 3(7), 1467-1484. Retrieved from https://archive.aessweb.com/index.php/5007/article /view/2507.

- Saima Afzal, H. R. (2016). Socio-Cultural Causes of Kala Kali (Honour Killing). Retrieved from https://www.grrjournal.com/jadmin/Auther/31rvIol A2LALJouq9hkR/lC7oygt3BJ.pdf.

- Shahraz, Q. (2001). Holy Woman Hardcover February 19, 2001. Retrieved from https://www.amazon.com/Holy-Woman-QaisraShahraz/dp/1901969037.

- Weiss, A. M. (2016). Honour Unmasked: Gender Violence, Law, and Power in Pakistan. By Nafisa Shah. Karachi. Retrieved from https://www.cambridge.org/core/journals/journalof-asian-studies/article/abs/honour-unmaskedgender-violence-law-and-power-in-pakistan-bynafisa-shah-karachi-oxford-university-press-2016408-pp-isbn-9780199403431cloth/8BC7E6120B24A76B4075B.

- Zakaria, R. (2018). No let-up in 'honour' crime. Retrieved from 